\title{
Quality characteristics of Mul-kimchi added with chlorella water extract
}

\author{
Dong Chung Kim ${ }^{1} \cdot$ Man-Jin $\mathrm{In}^{2}$ (D)

\section{클로렐라 추출물을 첨가한 물김치의 품질특성}

\author{
김동청 ${ }^{1} \cdot$ 인 만진 $^{2}$
}

Received: 14 February 2018 / Accepted: 21 March 2018 / Published Online: 30 June 2018

(C) The Korean Society for Applied Biological Chemistry 2018

\begin{abstract}
The quality and microbiological characteristics of various Mul-kimchi prepared with addition of $0.02,0.05$, and $0.1 \%(\mathrm{w} / \mathrm{v})$ chlorella water extract (CWE) were investigated during fermentation for 7 days at $10^{\circ} \mathrm{C}$. The addition of CWE powder stimulated the growth of lactic acid bacteria and considerably improved the acid production. After 6 days fermentation, titratable acidity of CWE Mul-kimchi was $0.16-0.19 \%$ and was higher than that $(0.14 \%)$ of Mul-kimchi made without CWE. The lactic acid bacterial counts were increased rapidly in CWE Mul-kimchi during fermentation for 4 days. The sensory quality of Mul-kimchi added with 0.05 $0.1 \%$ CWE powder lightly enhanced in taste and overall acceptability among the tested Mul-kimchis preparations. When CWE Mul-kimchi preparations fermented for 6 days were incubated at $4^{\circ} \mathrm{C}$ for 15 days, their titratable acidities were continuously increased up to $0.21-0.26 \%$ but number of viable lactic acid bacteria were well maintained above $10^{7} \mathrm{CFU} / \mathrm{g}$ through storage period.
\end{abstract}

Keywords Lactic acid bacteria $\cdot$ Quality characteristics $\cdot$ Storage stability · Titratable acidity

Man-Jin In $(\bowtie)$

E-mail:manjin@chungwoon.ac.kr

${ }^{1}$ Department of Chemical Engineering, Chungwoon University, Incheon 22100, Republic of Korea

${ }^{2}$ Department of Human Nutrition and Food Science, Chungwoon University, Hongseong 32244, Republic of Korea

This is an Open Access article distributed under the terms of the Creative Commons Attribution Non-Commercial License (http://creativecommons. org/licenses/by-nc/3.0/) which permits unrestricted non-commercial use, distribution, and reproduction in any medium, provided the original work is properly cited.

\section{서 론}

우리나라의 김치 중 물김치는 다량의 소금물에 배추, 열무, 무 등을 주재료로, 양파, 마늘, 생강, 파 등을 부재료로 혼합하여 숙성시킨 것으로 배추김치와는 다르게 발효액을 주로 섭취하는 독특한 식품이다. 물김치에는 발효 과정에서 유산균에 의하여 생성된 젖산을 비롯한 발효산물과 재료에서 용출된 다양한 영 양성분이 함유되어 시원한 맛을 내므로 국수나 냉면의 육수용 으로도 사용되고 있다[1]. 김치 재료 면에서 물김치는 배추김치 에 비하여 많은 양의 물을 사용하므로 재료 조직의 연화가 빠 르고, 용출된 영양성분에 의하여 발효가 신속하게 진행되어 저 장성이 낮은 특징이 있다[2]. 따라서 현재까지 물김치에 대한 연구는 주로 여러 가지 새로운 부재료를 첨가[오미자 추출물[3], 모과 추출액[4], 산마늘[5], 함초 분말[6], 산채[7], 클로렐라 분 말[8]]하거나, 진동[9]과 같은 새로운 물리적 환경을 이용하여 물김치의 품질과 저장성을 향상시키는 분야에 집중되고 있다.

클로렐라는 담수 조류의 일종으로 단백질, 엽록소, 비타민, 미 네랄, 핵산 및 불포화지방산 등을 함유하고 있어 영양학적으로 우수하며[10], 여러 가지 생리활성[면역기능 향상[11], 항산화 [12], 항피로[13], 혈당강하[14], 간 기능 개선[15], 항염증[16]]을 나타내며, 특히 chlorella growth factor (CGF)라는 생리활성 성 분이 함유되어 있어 어린이의 성장 발육과 환자의 회복에 효과 가 큰 것으로 보고되었다[10]. 이에 따라 클로렐라를 식품소재 로 첨가하여 두부[17], 발효유[18], 치즈[19], 케이크[20], 유과 [21] 등의 품질과 기능성을 향상시키려는 연구가 진행되어왔다. 더불어 클로렐라 분말의 열수 추출물인 클로렐라 추출물은 분 자량 5-10 kDa의 황을 함유한 수용성 nucleotide-peptide 복합 체를 주성분으로 하는 $\mathrm{CGF}$ 가 함유되어 있어 미생물 생육 촉진 및 세포부활 효과가 있는 것으로 보고되었다[22]. 그러나 식품 소재로서 클로렐라 추출물의 응용은 식빵[23]과 요구르트[24]의 품질을 향상시키려는 연구 정도로 매우 미미하다.

그러므로 본 연구에서는 클로렐라 열수 추출물을 이용한 식 
품 연구의 일환으로 우리나라 식단에서 가장 쉽게 접할 수 있 는 물김치를 대상으로 클로렐라 추출물을 첨가한 물김치를 제 조하고, 클로렐라 추출물의 첨가가 물김치의 발효특성과 관능적 특성, 그리고 숙성된 물김치의 저장성에 미치는 영향을 조사하 였으며, 클로렐라 분말을 첨가한 물김치에 대한 기존의 보고[8] 와 비교하였다.

\section{재료 및 방법}

\section{재료}

물김치 제조에 사용된 무와 부재료인 밀가루(중력분, 대한제분), 파, 양파, 마늘, 소금(순도 $90 \%$, 정제염, 샘표, 서울, 대한민국) 는 농협 하나로 마트(충남, 홍성, 대한민국)에서 구입하였다. 클 로렐라 열수 추출물은 말토덱스트린이 $20 \%$ 함유되어 있는 CGF 2000 (대상(주), 서울, 대한민국) 분말을 사용하였다.

\section{물김치 제조}

물김치는 $\mathrm{Kim}$ 등의 방법[8]을 다소 수정하여 다음과 같이 제 조하였다. 일정한 크기 $(3 \times 1 \times 1 \mathrm{~cm})$ 로 절단하여 $3 \%$ 소금물에 6 시간 절인 후 수세한 무 $(20 \%)$ 를 $4 \%$ 밀가루 현탁액으로 조제 한 밀가루 풀 $(4.0 \%)$, 양파 $(2.0 \%)$, 파 $(2.0 \%)$, 마늘 $(1.0 \%)$ 을 첨가 하고 여기에 $1.0 \%$ 소금물 $1 \mathrm{~L}$ 를 넣어 물김치를 제조하였다. 클 로렐라 추출물 분말을 $0.02,0.05,0.1 \%(\mathrm{w} / \mathrm{w})$ 각각 첨가하였으 며 CGF 2000에 부형재로 사용된 말토덱스트린이 각 실험구에 서 동일의 농도가 되도록 추가하였다. 물김치는 $10^{\circ} \mathrm{C}$ 에서 7 일 간 발효시켰다.

\section{$\mathrm{pH}$ 와 적정산도}

물김치의 $\mathrm{pH}$ 는 $\mathrm{pH}$ meter (model 915DC, Istek, 서울, 대한민 국)를 이용하여 측정하였다. 물김치의 적정산도는 국물을 멸균 증류수로 10 배 희석하고 $0.01 \mathrm{~N} \mathrm{NaOH}$ 로 적정하여 젖산으로 나타내었으며 phenolphthalein을 지시약으로 사용하였다.

\section{환원당}

물김치 국물의 환원당 함량은 DNS (3,5-dinitrosalicylic acid)법 을 사용하여 분석하였으며 포도당을 표준물질로 이용하였다.

\section{젓산균수 측정}

물김치 국물 $1 \mathrm{~g}$ 을 무균적으로 채취하여 멸균 생리식염수로 희 석한 후 젖산균 배양용 배지(Lactobacillus MRS agar, Difco Laboratories, Detroit, MI, USA)에 $1 \mathrm{~mL}$ 씩 pour plate method 로 접종하고 $37^{\circ} \mathrm{C}$ 에서 24-36시간 배양하였다. 형성된 colony를 계측하여 시료 $\mathrm{g}$ 당 colony forming units $(\mathrm{CFU} / \mathrm{g})$ 로 나타내었다.

\section{저장성 조사}

물김치의 맛이 가장 우수하다고 판단되는 $\mathrm{pH} 4$ 부근인 숙성 6 일째 물김치를 $4^{\circ} \mathrm{C}$ 에서 15 일간 보관하면서 $\mathrm{pH}$, 적정산도, 젖산 균수의 변화로 경시적으로 조사하였다.

\section{관능검사와 통계분석}

숙성 6 일째의 물김치를 시료로 청운대학교 식품영양학과 대학
생 15 명을 대상으로 색, 향, 맛, 종합적인 기호도를 5점 척도법 [아주 싫다(1점), 보통이다(3점), 아주 좋다(5점)]으로 관능평가를 실시하였다. SPSS (Statistical Package for Social Science, SPSS Inc., Chicago, IL, USA, version 11.5)를 이용하여 관능 검사 결과는 통계처리 하였으며 $\mathrm{ANOVA}$ 로 $5 \%$ 수준에서 각 시 료간의 유의성을 Duncan's multiple range test로 검증하였다(유 의수준 $p<0.05)$.

\section{결과 및 고찰}

\section{$\mathrm{pH}$ 와 적정산도의 변화}

클로렐라 추출물 분말을 $0.02,0.05,0.1 \%(\mathrm{w} / \mathrm{w})$ 첨가하여 제조 한 물김치와 클로렐라 추출물을 첨가하지 않은 대조구를 10 에 서 7일간 숙성시키며 국물의 $\mathrm{pH}$ 변화를 경시적으로 측정하였 다(Fig. 1). 발효 0 일에 $0.02,0.05$ 및 $0.1 \%$ 클로렐라 추출물 물김치의 $\mathrm{pH}$ 는 $\mathrm{pH} 5.28,5.22,5.14$ 로 대조구 $(\mathrm{pH} 5.24)$ 와 매우 유사하였다. 이는 클로렐라 분말을 직접 물김치에 첨가하면 클 로렐라 분말 첨가량에 비례하여 초기 $\mathrm{pH}$ 가 높아지는 결과[8]와 는 상이하게 클로렐라 추출물의 첨가가 발효 전 물김치 $\mathrm{pH}$ 에 미치는 영향은 미미하였다. 모든 실험구에서 물김치의 $\mathrm{pH}$ 는 발 효 3일까지 큰 변화가 없었으나, 그 이후 발효 6 일에 $\mathrm{pH} 4.0$ 부근까지 매우 급격하게 감소하였다. 특히 발효 5일 후 대조구 의 $\mathrm{pH}$ 는 4.76 이며 클로렐라 추출물 물김치의 $\mathrm{pH}$ 는 4.52 (0.02\% 첨가), 4.53 (0.05\% 첨가), 4.59 ( $0.1 \%$ 첨가)로 클로렐 라 추출물을 첨가한 조건에서 더 낮은 $\mathrm{pH}$ 를 나타내었다. 이는 클로렐라 분말을 첨가하여 제조한 요구르트[18], 물김치[8] 그리 고 클로렐라 추출물을 첨가한 요구르트[24]에서와 동일한 경향 이었다. 발효과정에서 물김치의 적정산도는 발효 4일 이후부터 급격하게 증가하였으며 증가 정도는 $\mathrm{pH}$ 의 변화와 동일한 경향 이었다(Fig. 2). $\mathrm{pH} 4.0$ 부근인 발효 6 일째 대조구의 산도는 $0.14 \%$ 이며 클로렐라 추출물 물김치의 산도는 $0.16 \%(0.02 \%$ 첨 가), $0.17 \%$ ( $0.05 \%$ 첨가), $0.19 \%(0.1 \%$ 첨가)이었으나, 발효 7

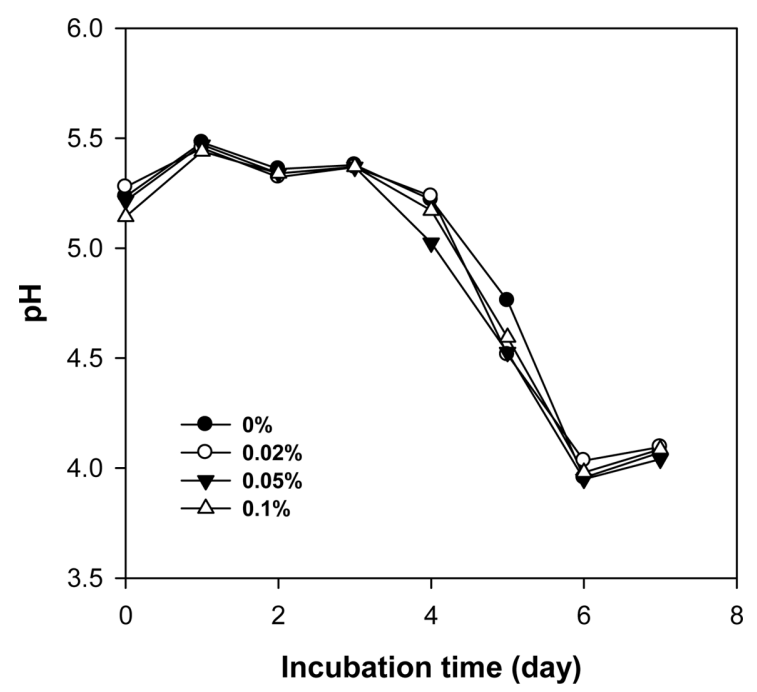

Fig. 1 Change in $\mathrm{pH}$ Mul-kimchi prepared with different levels of chlorella water extract during fermentation at $10^{\circ} \mathrm{C}$ for 7 days 


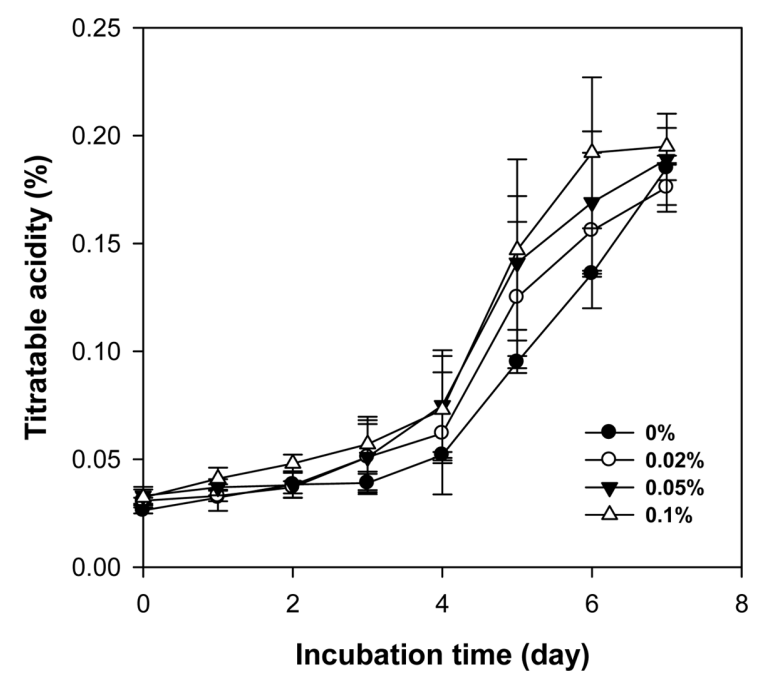

Fig. 2 Change in titratable acidity of Mul-kimchi prepared with different levels of chlorella water extract during fermentation at $10^{\circ} \mathrm{C}$ for 7 days

일에는 모든 실험구의 적정산도가 $0.18-0.19 \%$ 로 매우 유사하였 다. 이는 발효 과정에서 클로렐라 추출물에 의한 산의 생성이 클로렐라 추출물 첨가량에 비례하여 촉진되는 것을 나타내는 것 이다. 클로렐라 분말을 첨가 $(0.025-0.1 \%)$ 하고 $15^{\circ} \mathrm{C}$ 에서 6 일간 발효시킨 물김치의 적정산도 역시 본 연구와 유사하게 클로렐 라 분말의 첨가량에 비례하여 증가하였으며 모든 실험구에서의 적정산도가 $0.18-0.20 \%$ 라는 보고[8]를 고려하면 클로렐라 분말 에 함유된 산의 생성을 촉진하는 유효성분이 클로렐라 추출물 에도 함유되어 있는 것으로 판단되었다. 즉, 클로렐라 추출물이 물김치 숙성과정에서 $\mathrm{pH}$ 감소와 적정산도 증가를 촉진시켰으 며, 물김치의 숙성 적기가 $\mathrm{pH} 3.9 \pm 0.1$ 이라는 보고[25]에 따르 면 본 연구의 클로렐라 추출물 첨가 물김치를 $10^{\circ} \mathrm{C}$ 에서 발효시 키는 경우 발효 6 일이 적당한 것으로 판단되었다. 발효 6 일 이 후 미미한 $\mathrm{pH}$ 변화에도 적정산도는 증가하는 것은 김치 발효 중에 주로 생성되는 젖산과 초산은 해리상수가 작은 약산으로 다소 높은 농도로 축적되어도 $\mathrm{pH}$ 는 어느 한계값 이하로 낮아 지지 않기 때문이다. 본 연구에서 물김치의 숙성에 관한 많은 기존의 보고 $[3,4,5]$ 와 다소 상이한 $\mathrm{pH}$ 와 적정산도 값을 나타내 는 것은 물김치의 재료, 제조방법 및 숙성 조건의 차이에 기인 하는 것으로 사료되었다. 그럼에도 불구하고 발효과정에서 클로 렐라 추출물 물김치의 $\mathrm{pH}$ 와 적정산도의 변화는 기존의 보고와 매우 유사한 경향이었다.

\section{환원당과 젓산균 수의 변화}

클로렐라 추출물의 첨가량을 달리하여 제조한 물김치 국물의 환 원당 변화는 Fig. 3과 같다. 발효 초기에 환원당 함량은 점차 증가하여 발효 4 일에 대조구는 $0.42 \%$ 이며 클로렐라 추출물 물 김치는 $0.41 \% \quad(0.02 \%$ 첨가), $0.40 \% \quad(0.05 \%$ 첨가), $0.37 \%$ $(0.1 \%$ 첨가)로 최대값을 나타내었으며, 클로렐라를 첨가한 물김 치[8]에서와 유사하게 클로렐라 추출물의 첨가량이 증가할수록 환원당의 함량은 낮았다. 이는 발효과정에서 클로렐라 추출물이 물김치 중 환원당의 소모를 촉진시키는 것을 나타내는 것으로 클로렐라 추출물이 물김치의 발효속도를 증가시키는 것을 암시

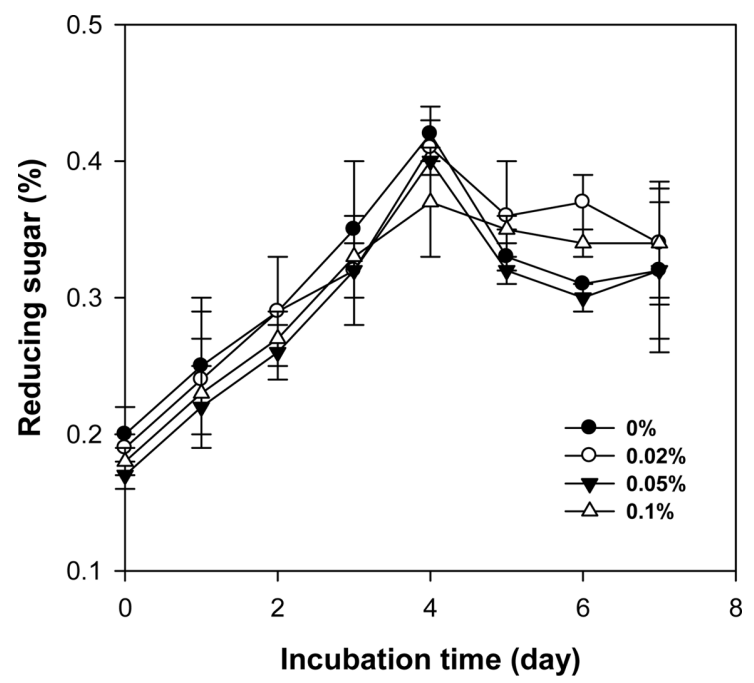

Fig. 3 Change in reducing sugar contents of Mul-kimchi prepared with different levels of chlorella water extract during fermentation at $10^{\circ} \mathrm{C}$ for 7 days

하고 있다. 발효 4일 후 환원당의 농도는 감소하여 발효 7일에 대조구는 $0.32 \%$, 클로렐라 추출물 $0.02,0.05$ 및 $0.1 \%$ 첨가 물 김치는 각각 $0.34,0.32,0.34 \%$ 로 클로렐라 추출물 물김치에서 다소 높게 나타났다. 발효 초기에 환원당이 증가는 무에 있는 펙틴질이 자가효소에 의한 분해[26]와 부재료로 첨가한 밀가루 풀의 전분이 물김치 발효조건에서 무에 함유된 amylase에 의한 분해[8]에 기인하며, 발효 중기 이후에 환원당의 감소는 미생물 이 번식하여 환원당이 젖산균 등의 영양원으로 이용되고 유기 산, 알코올, 이산화탄소 등의 물질로 변환[27]되기 때문이다. 본 연구와 같이 발효 초기 환원당이 증가한 후 점차 감소하여 발 효 후기 대조구에 비하여 높은 환원당 함량을 나타내는 결과는 매실즙을 첨가한 열무 물김치[26]와 함초 분말을 첨가한 열무 물김치[6]에서와 유사한 경향이었다. 클로렐라 추출물 첨가량을 달리하여 제조한 물김치 국물의 젓산균 수 변화는 Fig. 4와 같 다. 젖산균 수는 발효 0 일에 대조구 $2.27 \log \mathrm{CFU} / \mathrm{g}, 0.02$, 0.05 및 $0.1 \%$ 클로렐라 추출물 물김치는 $2.37,2.25 .2 .40 \mathrm{log}$ $\mathrm{CFU} / \mathrm{g}$ 이었으며, 발효 4일째는 각각 $6.72,7.51,7.65,7.26 \mathrm{log}$ $\mathrm{CFU} / \mathrm{g}$ 로 증가하여 클로렐라 추출물에 의하여 젖산균의 생육이 촉진되는 것을 나타내었다. 발효 4일까지 클로렐라 추출물에 의 한 젖산균 빠른 증가는 발효 4 일째 대조구의 환원당 함량보다 클로렐라 추출물 물김치의 환원당 함량 낮은 결과와 잘 일치하 였다. 발효 6 일 이후에는 클로렐라 추출물의 첨가와 무관하게 모든 물김치에서 8.38-8.59 $\log \mathrm{CFU} / \mathrm{g}$ 수준까지 증가하였다. 물 김치 국물의 젖산균 수는 $\mathrm{pH}$ 감소(Fig. 1)와 적정산도 증가(Fig. 2)와 동일하게 클로렐라 추출물 첨가 실험구에서 증가하였으므 로 $\mathrm{pH}$ 감소와 적정산도 증가는 젖산균 수의 증가에 기인하는 것이며 클로렐라 추출물에 의하여 젖산균의 증식이 촉진된 것 을 의미한다. 물김치 발효과정에서 클로렐라와 클로렐라 추출물 의 젓산균의 경시적인 변화에 대한 효과를 비교하면, 클로렐라 와 클로렐라 추출물은 모두 젖산균의 빠른 성장에 효과가 있었 으며, 클로렐라는 클로렐라 추출물에 비하여 물김치에서 대조군 보다 총 젖산균수도 증가시키는 효과[8]가 있었다. 이러한 차이 는 클로렐라 추출물 제조공정의 낮은 수율[28]로 인하여 버려 


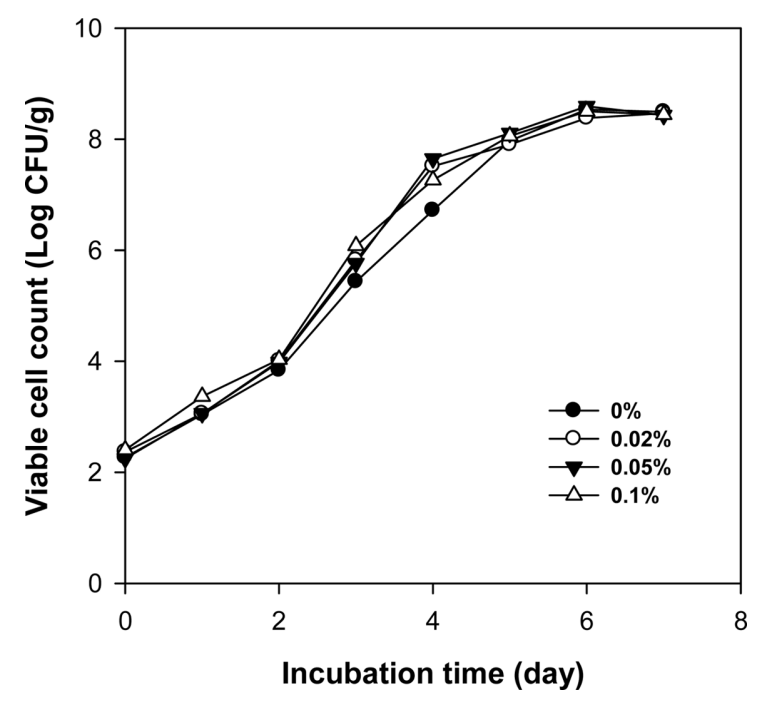

Fig. 4 Change in lactic acid bacteria counts of Mul-kimchi prepared with different levels of chlorella water extract during fermentation at $10^{\circ} \mathrm{C}$ for 7 days

지는 유용한 성분들이 클로렐라를 첨가하는 경우 젖산균의 증 식에 활용되기 때문인 것으로 판단되었다. 이러한 결과는 클로 렐라와 클로렐라 열수 추출물이 방선균[29], 젖산균[18,24]의 증 식을 촉진한다는 보고와 일치하였다. 특히 효모의 성장을 촉진 시키는 분자량 $642.9 \mathrm{Da}$ 의 알라닌, 글루탐산, 트레오닌을 함유 한 당펩타이드가 클로렐라 추출물에 함유되어 있음이 보고되어 있다[30].

\section{관능특성}

클로렐라 추출물 분말을 $0.02,0.05,0.1 \%(\mathrm{w} / \mathrm{w})$ 첨가하여 제조 한 물김치와 클로렐라 추출물을 첨가하지 않은 물김치를 $10^{\circ} \mathrm{C}$ 에서 6 일간 숙성시킨 후 색, 향, 맛, 그리고 종합적인 기호도에 대한 관능평가 결과는 Table 1과 같다. 모든 항목에서 클로렐 라 첨가량에 따른 관능적인 특성은 통계적으로 유의적인 차이 가 관찰되지는 않았다. 특히 색과 향에 대하여 클로렐라를 첨
Table 1 Sensory evaluation results of Mul-kimchi prepared with different levels of chlorella water extract after fermentation at $10^{\circ} \mathrm{C}$ for 6 days

\begin{tabular}{ccccc}
\hline \hline $\begin{array}{c}\text { Chlorella } \\
\text { extract (\%) }\end{array}$ & Color & Flavor & Taste & $\begin{array}{c}\text { Overall } \\
\text { acceptability }\end{array}$ \\
\hline 0 & $3.13 \pm 0.64^{1)}$ & $2.87 \pm 0.83$ & $2.93 \pm 0.96$ & $2.93 \pm 0.80$ \\
0.02 & $3.27 \pm 0.71$ & $3.00 \pm 0.85$ & $3.07 \pm 0.80$ & $3.13 \pm 0.74$ \\
0.05 & $3.33 \pm 0.72$ & $2.93 \pm 0.96$ & $3.13 \pm 0.92$ & $3.47 \pm 0.99$ \\
0.1 & $3.33 \pm 0.72$ & $3.13 \pm 0.92$ & $3.47 \pm 1.06$ & $3.13 \pm 1.06$ \\
\hline
\end{tabular}

${ }^{1)}$ Data are means $\pm \mathrm{SD}(\mathrm{n}=15)$

${ }^{2}$ Different superscripts within column indicate significant difference ( $p$ $<0.05)$

가한 물김치에서는 클로렐라의 진한 초록색과 특유의 향이 기 호도를 낮추는 것으로 보고[8]되었으나 클로렐라 추출물은 특유 의 색과 향이 없어 대조구와 첨가구에서 모두 매우 유사하였다. 맛은 통계적으로 큰 차이는 없으나 클로렐라 추출물의 첨가량 에 비례하여 $0.1 \%$ 첨가에서 3.47 점으로 가장 우수하였다. 종합 적인 기호도는 클로렐라 추출물을 첨가한 실험구와 대조구 간 에는 유의적으로 차이가 관찰되지 않았으나 $0.05 \%$ 클로렐라 물 김치가 3.47 점으로 가장 높게 나타났으며 대조구는 2.93점으로 기호도가 다소 감소하였다. 이상의 관능평가로부터 클로렐라 추 출물의 첨가는 클로렐라와는 상이하게 물김치의 색과 향의 기 호도를 낮추지 않고 물김치의 맛과 종합적인 기호도를 다소 증 진시키는 효과를 나타내었다. 그러므로 물김치 제조에서 클로렐 라 추출물은 클로렐라보다 효과적인 부재료로 판단되었다. 본 연구에서 적절한 클로렐라 추출물의 첨가량은 $0.05-0.1 \%$ 인 것 을 사료되었다.

\section{저장성}

주로 저온에서 보관, 유통되는 물김치의 저장 기간 중 품질 안 정성을 확인하기 위하여 클로렐라 추출물의 첨가량을 달리하여 담근 물김치를 $10^{\circ} \mathrm{C}$ 에서 6 일간 숙성시킨 후 $4^{\circ} \mathrm{C}$ 에서 냉장 보 관하면서 $\mathrm{pH}$, 적정산도 및 젖산균 수의 변화를 경시적으로 조 사하였다(Table 2). 저장 15 일까지 대조구와 클로렐라 추출물 첨 가 물김치의 $\mathrm{pH}$ 는 거의 변화하지 않았다. 그러나 적정산도는

Table 2 Changes in quality of Mul-kimchi prepared with different levels of chlorella water extract during storage at $4^{\circ} \mathrm{C}$

\begin{tabular}{|c|c|c|c|c|c|c|c|c|c|}
\hline & \multirow{2}{*}{$\begin{array}{c}\text { Chlorella extract } \\
(\%)\end{array}$} & \multicolumn{8}{|c|}{ Storage period (day) } \\
\hline & & 0 & 2 & 5 & 7 & 9 & 11 & 13 & 15 \\
\hline \multirow{4}{*}{$\mathrm{pH}$} & 0 & 4.09 & 4.19 & 4.16 & 4.15 & 4.14 & 4.05 & 4.12 & 4.08 \\
\hline & 0.02 & 4.05 & 4.17 & 4.13 & 4.11 & 4.09 & 3.98 & 4.06 & 4.03 \\
\hline & 0.05 & 4.02 & 4.13 & 4.12 & 4.12 & 4.12 & 4.01 & 4.10 & 4.07 \\
\hline & 0.1 & 4.13 & 4.23 & 4.17 & 4.15 & 4.14 & 4.02 & 4.12 & 4.07 \\
\hline \multirow{4}{*}{$\begin{array}{c}\text { Titratable } \\
\text { acidity } \\
(\%)\end{array}$} & 0 & $0.12 \pm 0.009^{1)}$ & $0.14 \pm 0.005$ & $0.16 \pm 0.009$ & $0.17 \pm 0.005$ & $0.19 \pm 0.014$ & $0.204 \pm 0.010$ & $0.22 \pm 0.005$ & $0.21 \pm 0.010$ \\
\hline & 0.02 & $0.14 \pm 0.005$ & $0.16 \pm 0.005$ & $0.20 \pm 0.009$ & $0.20 \pm 0.002$ & $0.23 \pm 0.005$ & $0.26 \pm 0.009$ & $0.26 \pm 0.005$ & $0.25 \pm 0.018$ \\
\hline & 0.05 & $0.12 \pm 0.005$ & $0.14 \pm 0.005$ & $0.19 \pm 0.010$ & $0.19 \pm 0.005$ & $0.22 \pm 0.005$ & $0.26 \pm 0.016$ & $0.25 \pm 0.009$ & $0.23 \pm 0.001$ \\
\hline & 0.1 & $0.13 \pm 0.010$ & $0.16 \pm 0.005$ & $0.20 \pm 0.005$ & $0.21 \pm 0.014$ & $0.23 \pm 0.001$ & $0.28 \pm 0.014$ & $0.28 \pm 0.005$ & $0.26 \pm 0.010$ \\
\hline \multirow{4}{*}{$\begin{array}{c}\text { Viable cell } \\
\text { counts } \\
(\mathrm{CFU} / \mathrm{g})\end{array}$} & 0 & $1.01 \times 10^{8}$ & $9.27 \times 10^{7}$ & $8.27 \times 10^{7}$ & $8.63 \times 10^{7}$ & $6.03 \times 10^{7}$ & $3.50 \times 10^{7}$ & $3.13 \times 10^{7}$ & $4.67 \times 10^{7}$ \\
\hline & 0.02 & $1.25 \times 10^{8}$ & $6.00 \times 10^{7}$ & $7.03 \times 10^{7}$ & $9.30 \times 10^{7}$ & $9.87 \times 10^{7}$ & $8.20 \times 10^{7}$ & $5.17 \times 10^{7}$ & $6.73 \times 10^{7}$ \\
\hline & 0.05 & $1.41 \times 10^{8}$ & $6.80 \times 10^{7}$ & $7.53 \times 10^{7}$ & $9.63 \times 10^{7}$ & $8.23 \times 10^{7}$ & $5.60 \times 10^{7}$ & $3.57 \times 10^{7}$ & $3.50 \times 10^{7}$ \\
\hline & 0.1 & $1.22 \times 10^{8}$ & $5.83 \times 10^{7}$ & $5.97 \times 10^{7}$ & $6.83 \times 10^{7}$ & $7.30 \times 10^{7}$ & $4.20 \times 10^{7}$ & $2.80 \times 10^{7}$ & $4.33 \times 10^{7}$ \\
\hline
\end{tabular}

${ }^{1)}$ Data are means $\pm \mathrm{SD}(\mathrm{n}=3)$ 
조금씩 증가하여 저장 15 일에는 첫날에 비하여 약 2 배 증가하 였으며, 클로렐라를 첨가한 물김치를 $4^{\circ} \mathrm{C}$ 에서 저장하면 적정산 도가 약간 증가한다는 결과[8]와는 다소 상이하였다. 적정산도 의 증가는 저장 중 젖산균의 대사활동이 천천히 진행되고 있어 산이 지속적으로 생성되기 때문인 것으로 사료되었다. 저장 중 젖산균 수는 모든 물김치에서 공히 저장 2 일 후에 $10^{7} \mathrm{CFU} / \mathrm{g}$ 수준으로 약간 감소하였으나 저장 15 일까지 $10^{7} \mathrm{CFU} / \mathrm{g}$ 이상으 로 유지되어 $-1^{\circ} \mathrm{C}$ 에서 저장하면 11 일부터 젖산균 수가 $10^{7}$ $\mathrm{CFU} / \mathrm{g}$ 이하로 감소하였다는 열무 물김치[31]보다 젖산균의 안 정성이 다소 우수하였다. 클로렐라 추출물 첨가 물김치가 다소 높은 산도를 나타내지만 $4^{\circ} \mathrm{C}$ 에서의 저장성은 15 일까지 대조구 와 유사하였다.

\section{초 록}

클로렐라 추출물을 식품재료로 사용하기 위하여 클로렐라 추출 물을 $0-0.1 \%$ 첨가한 물김치를 제조하여 10 에서 7일간 발효시 키면서 $\mathrm{pH}$, 적정산도, 젖산균수 및 관능적 특성을 조사하였다. $\mathrm{pH}$ 는 발효 3 일 이후 감소하기 시작하여 발효 5 일 후 클로렐라 추출물을 첨가한 조건에서 $\mathrm{pH}$ 5.14-5.28에서 4.52-4.59로, 대 조구는 $\mathrm{pH}$ 5.24에서 4.76으로 하락하였다. 적정산도는 발효가 진행됨에 따라 증가하여 발효 6 일째 대조구는 $0.14 \%$, 클로렐라 추출물 첨가구는 $0.16-0.19 \%$ 로 클로렐라 추출물의 첨가량에 비 례하여 증가하였다. 환원당 함량은 발효 4일에 최대값을 보였 으며 클로렐라 추출물의 첨가량이 증가할수록 환원당의 함량은 낮았다. 클로렐라 추출물에 의하여 젖산균의 생육이 촉진되어 발효 4일까지 클로렐라 추출물 물김치에서 젓산균 수가 빠르게 증가하였다. 관능평가에서 클로렐라 추출물의 첨가는 물김치의 색과 향에 대한 기호도를 낮추지 않았으며 맛과 종합적인 기호 도를 다소 증진시키는 효과를 보였다. 클로렐라 추출물 물김치 를 4 에서 15 일간 저장하는 동안 $\mathrm{pH}$ 의 변화는 미미하였고 적정 산도는 지속적으로 증가하였으며, 젖산균 약간 감소하였으나 전 체적으로 $10^{7} \mathrm{CFU} / \mathrm{g}$ 이상으로 유지되었다.

Keywords 저장성 - 적정산도 · 젖산균 · 품질특성

감사의 글 본 연구는 2017 년도 청운대학교 학술연구조성비의 지원을 받아 수행하였습니다.

\section{References}

1. Choi SY, Oh JY, Yoo JY, Hahn YS (1998) Fermentation properties of Yulmoo Mul-kimchi according to the ratio of water to yulmoo. Korean J Soc Food Sci 14: 327-332

2. Kim HR, Park JE, Jang MS (2002) Effect of perilla seed paste on the Yulmoo Mul-kimchi during fermentation. Korean J Soc Food Cookery Sci 18: 290-299

3. Jeong TS, Jeong EJ, Lee SH (2008) Effects on the quality characteristics of Mul-kimchi with Omija (Schizanadra chinensis Baillon) water extract. J Korean Soc Food Sci Nutr 37: 1301-1306

4. Park LY, Jeong TS, Lee SH (2008) Effects of chaenomelis fructus water extract on the quality characteristics of Mul-kimchi during fermentation. Korean J Food Preserv 15: 669-674
5. Park GS, Kim GS (2008) Quality characteristics of Allium victorialis Mul-kimchi during fermentation. Korean J Food Cookery Sci 24: 829 836

6. Park JE, Lee JY, Jang MS (2011) Quality characteristics of Yulmoo Mulkimchi containing saltwort (Salicornia herbacea L.). J Korean Soc Food Sci Nutr 40: 1006-1016

7. Lee HY, Kwon HJ, Park AR, Choi BK, Heo NK (2014) The quality changes of watery Kimchi made of wild vegetables by the pre-treatment methods. Korean J Culinary Res 20: 136-146

8. Kim DC, Won SI, In MJ (2014) Preparation and quality characteristics of Mul-kimchi added with chlorella. J Appl Biol Chem 57: 23-28

9. Kim GN, Han S, Kim EJ, Lee SD (2007) Influence of vibration on freezing and fermentation of watery Kimchi. J Korean Soc Food Sci Nutr 36: 1094-1097

10. Kang MS, Sim SJ, Chae HJ (2004) Chlorella as a functional biomaterial. Korean J Biotechnol Bioeng 19: 1-11

11. Guzman S, Gato A, Lamela M, Freire-Garabal M, Galleja JM (2003) Anti-inflammatory and immunomodulatory activities of polysaccharide from Chlorella stigmatophora and Phaeodactylum tricornutum. Phytother Res 17, 665-670

12. Shibata S, Natori $Y$, Nishihara T, Tomisaka K, Matsumoto K, Sansawa H, Nguyen VC (2003) Antioxidant and anti-cataract effects of Chlorella on rats with streptozotocin-induced diabetes. J Nutr Sci Vitaminol 49: 334-339

13. An HJ, Seo SW, Sim KS, Kim JS, Kim EH, Lee MO, Park HS, Han JG, Lee EH, Um JY, Hong SH, Kim HM (2006) Antifatigue effect of Chlorella vulgaris in mice. Korean J Food \& Nutr 19: 169-175

14. Cherng JY, Shih MS (2006) Improving glycogenesis in streptozocin (STZ) diabetic mice after administration of green algae Chlorella. Life Sci 78: 1181-1186

15. Shim JY, Shin HS, Han JG, Park HS, Lim BL, Chung KW, Om AS (2008) Protective effects of Chlorella vulgaris on liver toxicity in cadmium-administered rats. J Med Food 11: 479-485

16. Choi YJ, Jo WS, Kim HJ, Nam BH, Kang EY, Oh SJ, Lee GA, Jeong MH (2010) Anti-inflammatory effect of Chlorella ellipsoidea extracted from seawater by organic solvents. Korean J Fish Aquat Sci 43: 39-45

17. Kim SS, Park MK, Oh NS, Kim DC, Han MS, In MJ (2003) Studies on quality characteristics and shelf-life of chlorella soybean curd (tofu). J Korean Soc Agric Chem Biotechnol 46: 12-15

18. Sung YM, Cho JR, Oh NS, Kim DC, In MJ (2005) Preparation and quality characteristics of curd yogurt added with chlorella. J Korean Soc Appl Biol Chem 48: 60-64

19. Heo JY, Shin HJ, Oh DH, Cho SK, Yang CJ, Kong IK, Lee SS, Choi KS, Choi SH, Kim SC, Choi HY, Bae I (2006) Quality properties of Appenzeller cheese added with Chlorella. Korean J Food Sci Ani Resour 26: 525-531

20. Kim KJ, Chung HC (2010) Quality characteristics of yellow layer cake containing different amounts of chlorella powder. Korean J Food Cookery Sci 26: 860-865

21. Cho HS, Kim KH (2016) Effects of chlorella powder on quality characteristics of Yukwa. J Korean Soc Food Cult 31: 178-187

22. Han JG, Kang KK, Kim JK, Kim SH (2002) The present status and prospect of chlorella extract. Food Sci Industry 35: 64-69

23. Park SI (2003) Effect of chlorella growth factor on quality of bread. Korean J Food Cult 18: 356-364

24. Cho EJ, Nam ES, Park SI (2004) Effect of chlorella extract on quality characteristics of yoghurt. Korean J Food \& Nutr 17: 1-7

25. Yang YH, Park SH, Ann SM, Kim KM, Kim MR (2005) Physicochemical and sensory characteristics of Mul-kimchi (watery Kimchi) prepared with red cabbage. J East Asian Soc Dietary Life 15: 574-581

26. Jang MS, Park JE (2004) Effect of maesil (Prunus mume Sieb. et Zucc) juice on Yulmoo Mul-kimchi fermentatiom. Korean J Food Cookery Sci 20: 511-519

27. Cho Y, Lee HS (1991) Effect of lactic acid bacteria and temperature on 
Kimchi fermentation. Korean J Soc Food Cookery Sci 7: 15-25

28. In MJ, Jang JE, Kim DH (2007) Enhancing extraction yield of chlorella extract by enzyme treatment. J Appl Biol Chem 50: 132-135

29. Nakao H, Maeda T, Kuwatsuka S (1996) Effects of hot water extract and its residues of chlorella cells on the growth of radish seedlings and the changes in soil microflora. Jpn J Soil Plant Nutr 67: 17-23

30. Kanno T, Shinpo K, Masada M, Tamura G (1996) Growth-promoting factor for yeast from an extract of Chlorella vulgaris CK-5. SeibutsuKogaku Kaishi 74: 159-162

31. Park YH, Seo HJ, Cho IY, Han GJ, Chun HK (2007) Changes of quality characteristics and nitrate contents in Ulgari-Baechu Kimchi, Yulmoo Kimchi and Yulmoo Mul-kimchi during storage period. J Korean Soc Food Sci Nutr 36: 794-799 